Research Paper

\title{
Distribution of ABO Blood Groups and Rhesus Factor Percentage Frequencies Amongst the Populations of Sikkim, India
}

\author{
JAYANTI RAI and BISU SINGH* \\ Department of Zoology, School of Life Sciences, Sikkim University, Samdur, Tadong, Gangtok 737 102, \\ Sikkim, India
}

(Received on 23 September 2016; Revised on 24 October 2016; Accepted on 20 December 2016)

\begin{abstract}
The incidence of $\mathrm{ABO}$ and $\mathrm{Rh}$ blood group has been found to vary in various populations. The present investigation was undertaken with the aim to study ABO blood group frequency amongst a subset of population of Sikkim. A total of 5098 individuals were included in the study out of which 215 were students of Department of Zoology, Sikkim University and Government College, Tadong, East Sikkim, 3000 individuals were from Rinchenpong and 1883 individuals were from Bermiok, Berfok, Berthang, Martam, Chingthang, Deythang, Hatidhunga, Samdong, Sangadorjee and Yangsum of West Sikkim. The data for ABO blood group were collected from the register of Primary Health Centre, Rinchenpong and others by documenting blood group of the individuals who have undergone routine blood group testing in diagnostic laboratories. SPSS software Version 8 was used to perform statistical analysis. The results were calculated as frequencies of each of the blood group, expressed as percentages. The frequency of blood group A $(35.34 \%)$ was found to be the highest, followed by blood group O (35.18\%), B (21.99\%) and AB (7.49\%). The results also indicated that $99.47 \%$ of individuals were $\mathrm{Rh}$ positive and $0.53 \%$ were $\mathrm{Rh}$ negative. One of the interesting findings in the present study is the absence of Rh negative individuals among Bhutia population. The study may give preliminary idea about blood group frequency distribution among the population of Sikkim.
\end{abstract}

Keywords: Sikkim; Blood Group; Frequency; Population; Lepcha; Bhutia; Nepali

\section{Introduction}

Sikkim is one of the states in North Eastern India which is divided into four districts, North, South, East and West. It is situated between $27^{\circ} 04^{\prime}$ South to $28^{\circ}$ $07^{\prime}$ North and $88^{\circ} 01^{\prime}$ to $88^{\circ} 55^{\prime}$ East longitudes. The total population of Sikkim is 6,07,688 (census 2011), which mainly consists of Bhutia, Lepcha and Nepali.

The existence of $\mathrm{ABO}$ and Rhesus (Rh) antigens is clinically very important as it plays a major role in blood transfusion and organ transplantation. Though all the population of the world have same blood group system, but the frequency of $\mathrm{ABO}$ and $\mathrm{Rh}$ antigens is found to vary amongst all populations. Thus, many studies have found difference of $\mathrm{ABO}$ and $\mathrm{Rh}$ frequency among the world population (Zahra et al., 2014; Kostovski et al., 2014). Several studies have also been conducted to understand the distribution of
ABO blood group frequency among the Indian population (Gauniyal, 2006; Subhashini, 2007; Periyavan et al., 2010; Rai and Kumar, 2011; Pathania, 2011; Haloi, 2011; Pandey et al., 2012; Prakash et al., 2013; Pandey et al., 2013; Soram et al., 2014; Handoo and Bala, 2014; Rao and Shetty, 2014; Shrivastava et al., 2015; Sukumaran et al., 2016; Sah and Sahadalal, 2016). Overall distribution of ABO frequency in India shows the group $B$ to be the commonest blood group in northern and western part of India whereas in eastern, southern and central part $\mathrm{O}$ is the most prevalent blood group. Cumulatively, $\mathrm{O}$ is the dominant blood group among the Indian population (Shekhar et al., 2014).

Till date, only very few of the studies have been conducted to understand the distribution of ABO blood group frequency among the north-eastern population. As per the literature review, only one study have been

*Author for Correspondence: E-mail: bisusingh22@yahoo.co.in ; Ph. No. +919733155848 
conducted by Dutta and Banerjee (2008) to understand the $\mathrm{ABO}$ frequency in Sikkim, where blood group $\mathrm{O}$ was found to be predominant followed by $\mathrm{A}, \mathrm{B}$, and $\mathrm{AB}$. The major limitation of that study was very low sample size (142 individuals). Therefore, the present investigation was undertaken with the aim to study: (i) the $\mathrm{ABO}$ frequency among the population of Sikkim by taking larger sample size, (ii) incidence of ABO blood group among different communities of the state. The study may throw light on the distribution of blood group frequency in the state.

\section{Methods}

\section{Subjects}

A total of 5,098 individuals were included in this study, among them 2,490 (48.84\%) were females and 2,608 $(51.16 \%)$ were males. The ages of participants were from 5 to 99 years. The samples included populations such as Bhutia, Lepcha and Nepali. Further, the Nepali community itself consisted of Bhujel, Gurung, Jogi, Kami, Manger, Mukhia, Pradhan, Rai, Rawat, Sanayasi, Sharma, Sherpa, Subba, and Tamang.

\section{Determination of Blood Groups}

The ABO blood group data presented here is documented from 215 individuals of Sikkim University and Government College, Tadong who have undergone routine blood group testing in diagnostic laboratories. Further, ABO blood group data of 3000 individuals were collected from the recorded data of Rinchenpong, Primary Health Care unit. Moreover, the $\mathrm{ABO}$ blood frequency data were also generated from 1883 individuals of Bermiok, Berfok, Berthang, Martam, Chingthang, Deythang, Hatidhunga, Samdong, Sangadorjee, Yangsum by documenting the blood group from individuals who had undergone routine blood group testing in diagnostic laboratories.

\section{Statistical Analysis}

Statistical analysis was performed with the help of SPSS software, Version 8. The frequency of each $\mathrm{A}, \mathrm{B}, \mathrm{AB}, \mathrm{O}$ and $\mathrm{Rh}+, \mathrm{Rh}-$ blood group was calculated by direct count and later converted into percentage. The result was calculated as the frequency of each blood group expressed as percentage. Chi-square test was used to test the heterogeneity of population on the basis $\mathrm{ABO}$ frequency.

\section{Results}

In the present study, blood group A (35.34\%) was found to be the highest among the studied population followed by blood group O (35.18\%), B (21.99\%) and $A B(7.49 \%)$. The frequency was in the order of $\mathrm{A}>\mathrm{O}>\mathrm{B}>\mathrm{AB}$. Among the total population studied, $99.47 \%$ of individuals were Rh positive and $0.53 \%$ was Rh negative (Table 1).

Table 1. Distribution of $\mathrm{ABO}$ and $\mathrm{Rh}$ blood group percentage frequencies amongst the populations of Sikkim

\begin{tabular}{lcccc}
\hline Blood groups & Total & $\begin{array}{c}\text { Male } \\
\text { individuals }\end{array}$ & Female & $\%$ \\
\hline A & 1802 & 951 & 851 & 35.34 \\
O & 1793 & 878 & 915 & 35.18 \\
B & 1121 & 601 & 520 & 21.99 \\
AB & 382 & 178 & 204 & 7.49 \\
Total & 5098 & 2608 & 2490 & 100 \\
Rh +ve & 5071 & 2601 & 2470 & 99.47 \\
Rh-ve & 27 & 7 & 20 & 0.53 \\
Total & 5098 & 2608 & 2490 & 100 \\
\hline
\end{tabular}

Further, attempts were also made to study $\mathrm{ABO}$ frequency separately among Bhutia, Lepcha and Nepali population. The results showed that among 297 individuals of Bhutia community, blood group O (41.75\%; $n=124)$ was most prevalent followed by blood group B $(26.60 \% ; n=79), A(25.59 \% ; n=76)$ and $\mathrm{AB}(6.06 \% ; \mathrm{n}=18)$. The frequency of blood group was in the order of $\mathrm{O}>\mathrm{B}>\mathrm{A}>\mathrm{AB}$. With reference to Rh factor, Sikkimese Bhutia population showed presence of only $\mathrm{Rh}+$ blood group while $\mathrm{Rh}$ - group were completely absent in this ethnic group (Table 2 ). On the other hand, $A B O$ frequency among 688 Lepcha individuals showed a high percentage of blood group $\mathrm{A}(36.48 \% ; \mathrm{n}=251)$ followed by blood group $\mathrm{O}$ $(33.87 \% ; n=233), B(20.20 \% ; n=139)$ and $A B$ $(9.45 \% ; n=65)$. Most of the individuals were found to be $\mathrm{Rh}+(99.7 \%$; $\mathrm{n}=686)$. The frequency of blood group among the Lepcha population was in the order of $\mathrm{A}>\mathrm{O}>\mathrm{B}>\mathrm{AB}$. Among the Nepali community of Sikkim, blood group A (35.89\%; $\mathrm{n}=1476)$ was the most prevalent blood group, followed by blood group $\mathrm{O}$ $(34.91 \% ; n=1436), B(21.93 \% ; n=902)$, and $A B$ $(7.27 \% ; \mathrm{n}=299)$. The percentage of $\mathrm{Rh}+(99.39 \%$; $\mathrm{n}=4088$ ) was found to be the highest and $\mathrm{Rh}-$ was 
Table 2. ABO blood group distribution and its frequency among Bhutia, Lepcha and Nepali populations

\begin{tabular}{|c|c|c|c|c|c|c|c|c|c|c|}
\hline \multirow[b]{2}{*}{$\begin{array}{l}\text { Blood } \\
\text { groups }\end{array}$} & \multicolumn{3}{|c|}{ Bhutia } & \multicolumn{3}{|c|}{ Lepcha } & \multicolumn{3}{|c|}{ Nepali } & \multirow[b]{2}{*}{$\chi^{2}$} \\
\hline & $\begin{array}{c}\mathrm{Rh} \\
\text { positive }\end{array}$ & $\begin{array}{c}\mathrm{Rh} \\
\text { negative }\end{array}$ & $\%$ & $\begin{array}{c}\mathrm{Rh} \\
\text { positive }\end{array}$ & $\begin{array}{c}\mathrm{Rh} \\
\text { negative }\end{array}$ & $\%$ & $\begin{array}{c}\mathrm{Rh} \\
\text { positive }\end{array}$ & $\begin{array}{c}\mathrm{Rh} \\
\text { negative }\end{array}$ & $\%$ & \\
\hline $\mathrm{O}$ & 124 & 0 & 41.75 & 232 & 1 & 33.87 & 1426 & 10 & 34.91 & $0.994 \mathrm{df}=2 \mathrm{P}>5 \%$ \\
\hline B & 79 & 0 & 26.60 & 139 & 0 & 20.20 & 896 & 6 & 21.93 & $0.956 \mathrm{df}=2 \mathrm{P}>5 \%$ \\
\hline A & 76 & 0 & 25.59 & 251 & 0 & 36.48 & 1470 & 6 & 35.89 & $2.297 \mathrm{df}=2 \mathrm{P}>5 \%$ \\
\hline $\mathrm{AB}$ & 18 & 0 & 6.06 & 64 & 1 & 9.45 & 296 & 3 & 7.27 & $0.777 \mathrm{df}=2 \mathrm{P}>5 \%$ \\
\hline Total & 297 & 0 & 100 & 686 & 2 & 100 & 4088 & 25 & 100 & \\
\hline
\end{tabular}

only $0.61 \%(\mathrm{n}=25)$. Distribution of ABO blood groups among the Nepali population was in the order $\mathrm{A}>\mathrm{O}$ $>\mathrm{B}>\mathrm{AB}$. Chi-square test was also performed to study the heterogeneity among these populations on basis of $\mathrm{ABO}$ frequency distribution, which did not reveal any significant difference $(\mathrm{P}>0.05)$.

The Nepali community of Sikkim comprises number of populations within itself. The $\mathrm{ABO}$ and $\mathrm{Rh}$ blood group frequency of different populations under the Nepali community is presented in Table 3. The results show that $\mathrm{O}$ is the most frequent blood group among Chettri, Gurung, Sharma, Kami, Tamang, Jogi, and Rawat and group A is the most frequent blood group among Rai, Subba, Sherpa, Manger, Pradhan, Sanayasi, Bhujel, Rawat, whereas, B is the most frequent blood group among Mukhia population. Chisquare test among the Nepali population who have got sample size of more than hundred showed that the frequency of blood group $\mathrm{A}$ and $\mathrm{O}$ was significantly different $(\mathrm{P}<0.01)$ among Rai, Subba, Chettri, Gurung, Sharma, Kami, and Tamang (Table 3). On the other hand, frequency distribution of blood group $B$ and $A B$ were not significantly different. Moreover, there was no significant difference between $\mathrm{Rh}$ positive and negative frequency amongst all the populations.

Table 3. Distribution of ABO and Rh blood group within different populations of Nepali Community

\begin{tabular}{|c|c|c|c|c|c|c|c|}
\hline Nepali community & Total population & $\mathrm{A}(\%)$ & $\mathrm{B}(\%)$ & $\mathrm{O}(\%)$ & $\mathrm{AB}(\%)$ & $\mathrm{Rh}+\mathrm{ve}(\%)$ & Rh-ve(\%) \\
\hline Rai & 959 & 47.96 & 15.84 & 9.30 & 6.88 & 99.89 & 0.10 \\
\hline Subba & 798 & 43.98 & 16.54 & 28.69 & 10.77 & 99.74 & 0.25 \\
\hline Chettri & 601 & 27.95 & 25.12 & 40.93 & 5.99 & 98.50 & 1.49 \\
\hline Gurung & 658 & 32.82 & 24.92 & 37.38 & 0.04 & 100 & 0 \\
\hline Sharma & 465 & 16.98 & 30.10 & 46.02 & 6.88 & 99.78 & 0.21 \\
\hline Kami & 220 & 21.36 & 34.09 & 37.72 & 6.81 & 97.27 & 2.27 \\
\hline Tamang & 201 & 31.34 & 20.39 & 40.79 & 7.46 & 100 & 0 \\
\hline Chi square value & & $\begin{array}{c}23.7 \mathrm{df}=6 \\
\mathrm{P}<0.01 *\end{array}$ & $\begin{array}{c}11.6 \mathrm{df}=6 \\
\mathrm{P}>0.05\end{array}$ & $\begin{array}{c}26.2 \mathrm{df}=6 \\
\mathrm{P}<0.01 *\end{array}$ & $\begin{array}{c}9.6 \mathrm{df}=6 \\
\mathrm{P}>0.05\end{array}$ & $\begin{array}{c}0.06 \mathrm{df}=6 \\
\mathrm{P}>0.05\end{array}$ & $\begin{array}{c}7.4 \mathrm{df}=6 \\
\mathrm{P}>0.05\end{array}$ \\
\hline Sherpa & 64 & 48.43 & 23.43 & 21.87 & 6.25 & 100 & 0 \\
\hline Manger & 54 & 35.84 & 22.27 & 30.18 & 13.20 & 100 & 0 \\
\hline Pradhan & 43 & 44.18 & 18.60 & 32.55 & 4.65 & 100 & 0 \\
\hline Mukhia & 22 & 36.36 & 40.90 & 13.63 & 9.09 & 100 & 0 \\
\hline Sanayasi & 14 & 50 & 21.42 & 28.57 & 0 & 100 & 0 \\
\hline Bhujel & 8 & 62.5 & 12.5 & 12.5 & 12.5 & 100 & 0 \\
\hline Jogi & 4 & 25 & 0 & 50 & 25 & 100 & 0 \\
\hline Rawat & 2 & 50 & 0 & 50 & 0 & 100 & 0 \\
\hline
\end{tabular}

*significant 


\section{Discussion}

It was observed in the present study that blood group $\mathrm{A}$ is the most frequent blood group among the population of Sikkim followed by $\mathrm{O}, \mathrm{B}$ and $\mathrm{AB}$. However, frequency of A (35.34\%) and O (35.18\%) was found to be almost similar. In previous study by Dutta and Banerjee (2008), frequency of blood group $\mathrm{O}$ was found to be highest followed by $\mathrm{A}, \mathrm{B}$ and $\mathrm{AB}$, which is not in agreement with the present study. The present study found the highest frequency of blood group A among the population of Sikkim, which stands as a new finding. The difference between the present and previous study may be due to the large population size of the present study. Another reason for nonconcordance of the results may be confinement of previous study within Gangtok and East Sikkim areas only, whereas the present study was undertaken on samples from Gangtok, East Sikkim and from different parts of West Sikkim. Our result is in agreement with study by Gauniyal (2006) and Haloi (2011), but not in accordance to the study by Rai and Kumar (2011), Pathania (2011), and Saha and Sahadalal (2016).
A majority of people in the world have the Rh(D) positive blood group. Similarly, in the present study, the frequency of the $\mathrm{Rh}(\mathrm{D})$ among all ethnic population was found to be more than $95 \%$. On the other hand, the frequency distribution of Rh factor among Bhutia population shows the total absence of $\mathrm{Rh}$ negative group, which is a unique finding of the present investigation. The complete absence of Rh negative frequency was also observed among the tribal population of Jharkhand (Pandey et al., 2012). Comparative data on $\mathrm{ABO}$ and $\mathrm{Rh}$ frequency of various Indian populations at different geographical areas in India and abroad is presented in Table 4.

The study of $\mathrm{ABO}$ frequency separately among Bhutia, Lepcha and Nepali population showed variability in the distribution pattern, but when compared statistically it was not found to be significant. Therefore, it can be mentioned here that there is no heterogeneity among these populations on the basis of ABO blood group frequency (Table 2). On the other hand, comparison of $\mathrm{ABO}$ frequency among the various population of Nepali community revealed

Table 4. Comparison of frequency percentages of $\mathrm{ABO}$ and Rh groups at different geographical areas in India and abroad

\begin{tabular}{|c|c|c|c|c|c|c|c|}
\hline Location & Place of study & $\begin{array}{c}\text { Blood } \\
\text { group A \% }\end{array}$ & $\begin{array}{c}\text { Blood } \\
\text { group O\% }\end{array}$ & $\begin{array}{c}\text { Blood } \\
\text { group B\% }\end{array}$ & $\begin{array}{c}\text { Blood } \\
\text { group AB \% }\end{array}$ & $\begin{aligned} & \mathrm{Rh} \\
&+ \text { +ve } \%\end{aligned}$ & $\begin{array}{c}\mathrm{Rh} \\
-\mathrm{ve} \%\end{array}$ \\
\hline Eastern India & $\begin{array}{l}\text { Present study } \\
\text { Manipur (Soram et al., 2014) } \\
\text { Arunachal Pradesh (Prakash et al., 2013) } \\
\text { Meghalaya (Haloi 2011) } \\
\text { West Bengal (Sah and Sahadalal, 2016) } \\
\text { Jharkhand (Pandey et al., 2012) }\end{array}$ & $\begin{array}{c}35.34 \\
23.9 \\
13.0 \\
25.37 \\
13.31 \\
23.81\end{array}$ & $\begin{array}{c}35.18 \\
34.4 \\
42.0 \\
41.36 \\
31.27 \\
23.81\end{array}$ & $\begin{array}{c}21.99 \\
35.7 \\
40.0 \\
22.87 \\
36.52 \\
44.76\end{array}$ & $\begin{array}{c}7.49 \\
7.6 \\
5.0 \\
10.49 \\
10.15 \\
7.62\end{array}$ & $\begin{array}{c}99.47 \\
94.2 \\
99.0 \\
98.77 \\
99.97 \\
100\end{array}$ & $\begin{array}{c}0.53 \\
5.8 \\
1.0 \\
1.23 \\
0.03 \\
0\end{array}$ \\
\hline Western India & Southern Rajasthan (Shekhar 2014) & 22.3 & 34.4 & 35.7 & 7.6 & 94.2 & 5.8 \\
\hline North India & $\begin{array}{l}\text { Himachal Pradesh (Pathania, 2011) } \\
\text { Kashmir Valley (Handoo 2014) } \\
\text { Uttaranchal (Gauniyal, 2006) } \\
\text { Uttar Pradesh (Rai and Kumar, 2011) }\end{array}$ & $\begin{array}{c}27.0 \\
23.88 \\
40.69 \\
23.66\end{array}$ & $\begin{array}{c}24.0 \\
34.72 \\
23.72 \\
32.68\end{array}$ & $\begin{array}{c}31.0 \\
33.34 \\
22.03 \\
36.81\end{array}$ & $\begin{array}{c}18.0 \\
8.06 \\
11.86 \\
6.85\end{array}$ & $\begin{array}{l}89.3 \\
91.17 \\
89.27 \\
95.59\end{array}$ & $\begin{array}{c}10.7 \\
8.83 \\
10.73 \\
4.41\end{array}$ \\
\hline Central India & $\begin{array}{l}\text { Chattisgarh (Shrivastava et al., 2015) } \\
\text { Indore (Gupta and Dadwal, 2012) }\end{array}$ & $\begin{array}{c}22.17 \\
24.2\end{array}$ & $\begin{array}{c}33.55 \\
31.5\end{array}$ & $\begin{array}{c}35.42 \\
35.2\end{array}$ & $\begin{array}{c}8.17 \\
9.1\end{array}$ & $\begin{array}{c}96.85 \\
95.4\end{array}$ & $\begin{array}{c}3.15 \\
4.6\end{array}$ \\
\hline South India & $\begin{array}{l}\text { Karnataka (Rao and Shetty, 2014) } \\
\text { Bangalore (Periyavan et al., 2010) } \\
\text { Devangere (Periyavan } \text { et al., 2010) } \\
\text { Chittoor (Das et al., 2001) } \\
\text { Pondicherry (Subhashini, 2007) } \\
\text { Telangana (Sukumaran et al., 2016) } \\
\text { Karnataka (Rao and Shetty, 2014) }\end{array}$ & $\begin{array}{c}25.8 \\
23.85 \\
26.15 \\
18.95 \\
20.5 \\
18.31 \\
25.8\end{array}$ & $\begin{array}{c}42.0 \\
39.81 \\
36.72 \\
47.37 \\
34.0 \\
41.20 \\
42.0\end{array}$ & $\begin{array}{c}27.3 \\
29.95 \\
29.85 \\
25.79 \\
39.5 \\
35.86 \\
27.3\end{array}$ & $\begin{array}{c}4.8 \\
6.37 \\
7.25 \\
7.89 \\
6.0 \\
4.58 \\
4.8\end{array}$ & $\begin{array}{c}94.64 \\
94.20 \\
94.8 \\
90.6 \\
93.5 \\
96.18 \\
94.64\end{array}$ & $\begin{array}{c}5.35 \\
5.79 \\
5.52 \\
8.42 \\
6.5 \\
3.82 \\
5.35\end{array}$ \\
\hline Outside India & $\begin{array}{l}\text { Nepal (Pramanik and Pramanik, 2000) } \\
\text { West Iran (Zahara } \text { et al., 2014) } \\
\text { Macedonia (Kostovski } \text { et al., 2014) }\end{array}$ & $\begin{array}{c}34.0 \\
34.2 \\
34.45\end{array}$ & $\begin{array}{c}32.5 \\
33.7 \\
28.85\end{array}$ & $\begin{array}{c}29.0 \\
16.2 \\
15.66\end{array}$ & $\begin{array}{c}4.0 \\
7.0 \\
10.29\end{array}$ & $\begin{array}{c}96.66 \\
91.1 \\
89.26\end{array}$ & $\begin{array}{c}3.33 \\
8.9 \\
10.74\end{array}$ \\
\hline
\end{tabular}


significant difference in the frequency of blood group A and $O$ among Rai, Subba, Chettri, Gurung, Sharma, Kami, and Tamang (Table 3). This may be attributed to different races to which they belong such as Chettri, Sharma and Kami belong to Indo-Aryan group whereas Rai, Subba, Gurung, Tamang belong to Mongoloid group.

Most of the samples included in the present study were from West and East Sikkim and samples that were not included from South and North Sikkim, which is the limitation of present study. Taking this limitation into consideration, the present study still provides preliminary information about $\mathrm{ABO}$ and $\mathrm{Rh}$ frequency

\section{References}

Das P K, Nair S C, Harris V K, Rose D, Mammen J J, Bose Y N and Sudarsanam A (2001) Distribution of ABO and Rh-D blood groups among blood donors in a tertiary care-centre in South India Trop Doct 31 47-48

Dutta U K and Banerjee S (2008) A study of distribution of ABO and $\mathrm{Rh}(\mathrm{D})$ blood groups amongst Sikkimese J Indian Med Assoc 106 506-507

Gauniyal M (2006) The study of blood group A1A2BO and Rh among the Brahmins of Mussoorie, Uttaranchal Anthropologist 8 53-4

Gupta N K and Dadwal S (2012) Distribution of ABO and Rhesus-D Blood groups Asian J Trans Sci 6 73-4

Haloi A (2011) Genetic Characterization of the Biates of Saipung Village of Jaintia Hills District, Meghalaya Anthropologist 13 239-240

Handoo S and Bala S S (2014) Distribution of ABO and Rhesus Blood Groups in Kashmir Valley Internat J Sc Resch 3(9) 233-35

Kostovski M, Makarovska-Bojadzieva T and Blagoevska M (2014) Blood group distribution of ABO antigens and rhesus blood group system in the macedonian and Albanian population in the republic of Macedonia Int J Biol Med Re 5 3988-3990

Pandey B N, Jahangeer M D, Kumar D, Vatsal S and Verma D K (2013) Genetic structure and micro genetic differentiation among populations of Terai belt of Bihar, India European Journal of Experimental Biology 3 80-87

Pandey B N, Kumari R, Mishra A, Jahangeer K D and Ojha A K (2012) Genetic variation and micro-genetic differentiation among tribal populations of Jharkhand, India Scholarly among the population of Sikkim. The results of this study may be of immense help in providing background information for transfusion services.

\section{Acknowledgement}

Authors are grateful to the assistance provided by $\mathrm{Dr}$ Bhoj Kumar Acharya, Assistant Professor, Department of Zoology, Sikkim University for statistical analysis.

\section{Conflict of Interest}

The authors declare no conflict of interest.

Pathania I (2011) The Serological Variation Among Tribal and Non-Tribal population of Himachal Pradesh Biological Forum Biological Forum- An International Journal $344-$ 47

Periyavan A, Sangeetha S K, Marimuthu P and Manjunath B K (2010) Distribution of ABO and Rhesus-D, groups in and around Bangalore Asian J Transfus Sci 441

Prakash D S R S, Varma P J, Reddy S G and Dasgupta A (2013) Genetic Variation of Blood Group Polymorphism among an Endogamous Human Population from Andhra Pradesh, India. International Journal of Scientific Study $122-25$

Pramanik T and Pramanik S (2000) Distribution of ABO and Rh blood groups in Nepalese medical students East Mediterr Health $J 6$ 156-58

Rai V and Kumar P (2011) Genetic Analysis of ABO and Rh Blood Groups in Backward Caste Population of Uttar Pradesh, India Not Sci Bio 3 7-14

Rao C and Shetty J (2014) Frequency of ABO and rhesus (D) blood groups in Dakshina Kannada district of Karnataka A study from rural tertiary care teaching hospital in south India NUJHS 4 57-60

Sah A K and Sahadalal B (2016) Frequency and distribution of blood groups in the donors of a rural hospitals, Barasat, 24 Parganas, West Bengal, India Int J Pharm Bio Sci 7 414-418

Shekhar H, Kaur A, Jadeja P, Parihar P M and Mangukiya K K (2014) Frequency and distribution of ABO blood group and $\mathrm{Rh}(\mathrm{D})$ factor in southern Rajasthan International Journal of Science \& Nature 5 494-497

Shrivastava S, Gahine R and Kapse V (2015) ABO, rhesus blood 
group and allele frequency in and around Raipur (Chattisgarh state), India IJCRR 7 52-58

Soram J S, Panmei K and Biswas S P (2014) Distribution of ABO and $\mathrm{Rh}(\mathrm{D})$ blood group among the people of Mao naga Tribe of Mao, Senapati district of Manipur, North East India International Journal of Development Research 4 184-187

Subhashini A B (2007) Distribution of ABO and Rh (D) Blood Groups among Irulas a Tribal Population of Pondicherry, India Anthropologist 9 163-64
Sukumaran M K, Padma A S, Vanitha S, Rajani D and Padma S (2016) Frequency of ABO and Rh Blood Groups among High School Children of Alwal, Secunderabad, Telangana, India Journal of dental and medical sciences 15 47-49

Zahra G, Kouresh S, Majid Z and Seyed M S (2014) Distribution of $\mathrm{ABO}$ and $\mathrm{Rh}$ blood groups in a major ethnic group of the West Iran, the Kurdish population Asian Journal of Medical Science 5 26-29. 